\title{
Ennen poro ruokki poromiehen, nyt poromies ruokkii poron
}

Mauri Nieminen

Luke, Porontutkimusasema, Toivoniementie 246, 99910 Kaamanen, mauri.nieminen@luke.fi

\section{TIIVISTELMÄ}

Suomessa poronomistajia on enää 4000 ja alle 900 pitää porotaloutta elinkeinonaan. Ylä-Lapin kankailla jäkälämäärä pieneni 30 vuodessa $75 \%$, ja sitä on enää $120 \mathrm{~kg}$ kuivapainoa/ha. Poronhoitoalueen keski- ja eteläosassa jäkälää on vain $35 \mathrm{~kg} / \mathrm{ha}$. Määrät ovat 10-100 kertaa pienemmät kuin metsäpeuroilla Kuhmossa sekä tunturipeuroilla ja poroilla Etelä-Norjassa ja Kuolassa. Vaikka tunturialueesta on suojeltu yli $80 \%$, myös tunturikoivikot ovat ylilaidunnettuja ja uhanalaisia. Poroja ruokitaan talvisin kaikissa paliskunnissa ja yli 45 miljoonalla rehukilolla. Rehuista yli puolet on kaupallisia, ja säilörehua tuodaan myös poronhoitoalueen ulkopuolelta. Tällä rehumäärällä Suomen noin 200000 eloporoa elää yli neljä kuukautta.

Laitumiltaan kaksi kertaa suuremman Sallan paliskunnan poronhoito poikkeaa suuresti samassa kunnassa sijaitsevasta Pohjois-Sallasta. Kesälaitumia on kolme kertaa enemmän mutta jäkälää erittäin vähän. Eloporotiheys on siellä kaksi kertaa pienempi kuin Pohjois-Sallassa mutta talviruokinta on yleistä. Ruokintakulut olivat tutkimusvuosina 2005-13 Sallassa noin kuusi kertaa suuremmat kuin Pohjois-Sallassa, jossa poroja on ruokittu vähän vain paliskunnan eteläosassa. Sallassa poroelinkeinon tulos ilman peto- ja liikennevahinkokorvauksia sekä maataloustukia oli suurista ruokintakuluista johtuen negatiivinen, keskimäärin jopa 6000 euroa/poronomistaja.

Ruokinta ja kesyyntyminen ovat tuoneet Sallassa poroja taajamiin, pihoille, pelloille ja teille lisäten liikennevahinkoja. Vahinkokorvaukset nostivat hieman kokonaistulosta, ja maataloustukien myötä se oli yli 7000 euroa/poronomistaja. Pohjois-Sallassa lähes kaikki poronomistajat saivat puolestaan petokorvauksia ja paliskunta myös vasahävikkikorvausta. Keskimääräinen petovahinkokorvaus kasvoi nelinkertaisesti laskeviin myyntituloihin verrattuna. Poroelinkeinon tulos oli ilman petokorvauksia ja maataloustukia 2000 7700 euroa/poronomistaja. Kokonaistulos kasvoi nopeasti ja suuresti petovahinkokorvausten myötä, ja se oli lopulta keskimäärin yli 15000 euroa/poronomistaja. Kokonaistulos oli Pohjois-Sallan poronomistajilla ja pääasiassa luonnonlaitumilla yli kaksi kertaa suurempi kuin Sallassa. Veroja maksoi molemmissa paliskunnissa vuosittain vain muutama poronomistaja. Tutkimustulosten mukaan poroja pitäisi hoitaa paremman kannattavuuden, mutta myös hyvän imagon vuoksi enemmän luonnonlaitumilla. Porolaidunten riittävyyteen, kuntoon ja poromääriin pitäisi kiinnittää huomiota jo kasvavien liikenne- ja petovahinkojen vuoksi koko poronhoitoalueella.

Asiasanat:

Porotalous, laitumet, ruokinta, peto- ja liikennevahingot, tuet ja korvaukset, kannattavuus 


\section{Johdanto}

Suomessa poronomistajia on enää 4000 ja alle 900 pitää porotaloutta elinkeinonaan. Porojen talvilaidunten kunto on heikentynyt huomattavasti viime vuosina ylilaidunnuksen ja jäkälän vähentymisen vuoksi. Jäkälämäärät ovat 10-100 kertaa pienemmät kuin metsäpeuroilla Kuhmossa sekä tunturipeuroilla ja poroilla Etelä-Norjassa ja Kuolassa. Tunturialueesta on suojeltu yli $80 \%$, silti myös tunturikoivikot ovat ylilaidunnettuja ja uhanalaisia. Porojen talvinen maasto- ja/tai tarharuokinta on lisääntynyt entisestään. Ilman ruokintaa nykyiset poromäärät eivät selviydy paliskunnissa talven yli. Tuotantopanosten hinnat eivät ole kohonneet yhtä nopeasti kuin poronlihan, mutta kasvaneet ruokintakustannukset ovat heikentäneet porotalouden kannattavuutta. Ylimääräiset kustannukset koostuvat syötetyn rehun hinnasta ja työkuluista.

Poroja ruokitaan nykyään jo kaikissa paliskunnissa, Lapissa, Kemin-Sompiossa ja Pohjois-Sallassa vain niiden eteläosissa. Vuosittain 45 miljoonasta rehukilosta kuivapainoa yli puolet on kaupallisia, ja säilörehua tuodaan myös poronhoitoalueen ulkopuolelta. Tällä rehumäärällä noin 200000 eloporoa elää yli neljä kuukautta. Markkinatalous on muuttanut viime vuosikymmeninä myös poronhoitoa ja porokannan rakennetta. Ennen pohjoisten paliskuntien porotokista noin $40 \%$ oli hirvaita/härkiä. Nykyään niitä on enää 5-10\%. Vasovia vaatimia on porokannasta yli $80 \%$. Vasateurastus on yleistä. Urosporot olisivat yhä tärkeitä, sillä ne kaivavat ravintoa kovankin hangen alta ja helpottavat myös muiden porojen ravinnon saantia luonnonlaitumilla.

Poronhoitoalueella petojen ja myös niiden tappamien porojen määrä on kasvanut. Viimeisen 15 vuoden aikana poronhoitoalueen karhujen määrä on kaksinkertaistunut, ilvesten kolminkertaistunut ja ahmojenkin määrä on noussut viidenneksen. Viime vuosina ahmojen määrä on kaksinkertaistunut. Petovahingot ovat pahimmillaan itärajalla ja kaakkoisella poronhoitoalueella, jossa ne uhkaavat paikoin jo poronhoidon tulevaisuutta. Ahmavahingot ovat lisääntyneet eniten tunturialueella. Petovahinkojen vuoksi saadaan entistä vähemmän poronlihaa. Myös liikenteessä kuolee vuosittain jopa yli 5000 poroa. Lihantuotanto on silti edelleen porotalouden tärkein tulonlähde muodostaen lähes $60 \%$ tuloista. Peto- ja liikennekorvaukset lähinnä siitosporoista sekä tuet muodostavat reilun kolmanneksen ja muut tuotteet loput $10 \%$ tuloista.

Sallan kunnassa on kaksi paliskuntaa: Pohjois-Salla (nro 23) ja Salla (nro 24). Näiden paliskuntien poronhoitoa ja eloporoa kohti laskettua puhdasta tuottoa tutkittiin 2000-luvun alussa (Siitari ym. 2003). Paliskuntien poronhoidon ja taloudellisen tuloksen vertaaminen antoi jo hyvän kuvan poronhoidon tilasta ja eroista myös koko poronhoitoalueella. Tämän tutkimuksen tarkoituksena oli edelleen tutkia näiden kahden paliskunnan poronhoitoa, porotaloutta ja mahdollisia muutoksia sekä verrata poronomistajien porotalouden kokonaistulosta (Nieminen 2015a).

\section{Aineisto ja menetelmät}

Sallan kunnan pinta-ala on $5872 \mathrm{~km}^{2}$, josta vesistöä on $142 \mathrm{~km}^{2}$. Yhteistä rajaa Venäjän kanssa on $187 \mathrm{~km}$. Sallan elinkeinorakenne painottui 1970-80-luvuilla kovin alkutuotantoon, kuten maanviljelyyn, metsätalouteen ja poronhoitoon. Nykyään on kehitetty myös matkailua. Kunnassa on 4400 asukasta. Kirkonkylän jälkeen suurimpia kyliä ovat Kursu, Hautajärvi, Saija, Kotala ja Naruska. Kunnan eteläosan läpi Joutsijärveltä koilliseen Kelloselkään ja Venäjän rajalle kulkee kantatie 82. Kirkonkylästä etelään kulkee Seututie 950 ja Joutsijärveltä kaakkoon ja Kuusamoon valtatie 5. Seututie 965 kulkee Sallan läpi kaakkoon Kotalaan ja etelään Kelloselkään. Kotalasta on tie pohjoiseen Naruskaan ja Tuntsalle. Sallan pohjoisosa kuuluu Itä-Lapin tunturi- ja vaaraseutuun. Sille tyypillistä ovat jyrkkäpiirteiset, länteen loivenevat vaara- ja tunturialueet. Myös soiden määrä lisääntyy lännessä. Vuonna 1981 perustettu Värriön luonnonpuisto (125 $\mathrm{km}^{2}$ ) männiköineen ja karuine tunturipaljakoineen on tällä alueella. Eteläinen osa Sallaa kuuluu Kuusamon vaaraseutuun. Oulangan kansallispuistosta $\left(142 \mathrm{~km}^{2}\right)$ noin puolet on Sallan eteläosassa (Nieminen 2010).

Pohjois-Sallan paliskunta kuuluu erityisesti poronhoitoa varten tarkoitettuun ja Salla ns. muuhun poronhoitoalueeseen. Kangasmaita on Pohjois-Sallassa noin $1550 \mathrm{~km}^{2}$ ja Sallassa $2380 \mathrm{~km}^{2}$. PohjoisSallassa talvilaitumina tärkeiden kangasmaiden osuus maa-alasta on noin $73 \%$, kun niiden osuus Sallassa on $57 \%$. Soita, tärkeitä kesälaitumia, on Sallassa $1780 \mathrm{~km}^{2}$ ja Pohjois-Sallassa vain $574 \mathrm{~km}^{2}$ (Mattila 2014). Sallan paliskunta sijaitsee Peräpohjolan kasvimaantieteellisellä vyöhykkeellä, mutta Pohjois-Sallasta lähes puolet, eli pohjoisosa sijoittuu Metsä-Lappiin. Suurin sallittu eloporoluku on Pohjois-Sallassa 4 800, Sallassa 5 300. Eloporotiheys kangasmailla on Pohjois-Sallassa 3,1 ja Sallassa 2,2 poroa $/ \mathrm{km}^{2}$. Poronhoitovuonna 2012/13 luettiin Pohjois-Sallassa 4577 eloporoa, ja teurasporoja oli 1281 (28 \% eloporoista). Sallassa luettiin 5039 eloporoa ja teurasporoja oli 1612 (32\%). Pohjois-Sallassa oli 104 ja Sallassa 141 poronomistajaa. Pohjois-Sallassa kesälaitumia on yhteensä $1018 \mathrm{~km}^{2}$ (48\% laitumista), Sallassa $2936 \mathrm{~km}^{2}$ (68 
\%). Laadultaan ja käyttöajaltaan parasta kesäravintoa (ruohomaiset kasvit, heinät ja kortteet) oli hyvin ja enemmän Sallassa kuin Pohjois-Sallassa. Myös lehdeksiä on Sallassa selvästi enemmän kuin PohjoisSallassa. Eloporoa kohti laskien kesäravinnon kokonaismäärä on kaksinkertainen Sallan paliskunnassa verrattuna Pohjois-Sallaan (Kumpula ym. 1999).

Yli 30 vuodessa kangasmetsissä jäkälien keskibiomassa pieneni poronhoitoalueen keski- ja eteläosassa $40 \%$, ja jäkälää oli enää keskimäärin vain 35 kg kuivapainoa/ha (Mattila 2014). Vuonna 2004 PohjoisSallassa kangasmailla jäkälää oli keskimäärin noin $37 \mathrm{~kg} / \mathrm{ha}$ ja Sallassa vain $6 \mathrm{~kg} / \mathrm{ha}$. Metsälauhaa oli Pohjois-Sallassa keskimäärin 36 ja Sallassa 56 kg/ha (Mattila \& Mikkola 2009, Mattila 2012). Uusimmassa inventoinnissa Kemiankylän merkkipiirissä, johon Pohjois-Salla kuuluu, jäkälää oli keskimäärin $92 \mathrm{~kg} / \mathrm{ha}$. Sallan merkkipiirissä, johon Sallan paliskunta kuuluu, jäkälää oli vain $7 \mathrm{~kg} / \mathrm{ha}$. Metsälauhaa oli näissä paliskunnissa kangasmailla keskimäärin 34-54 kg/ha. Luppolaidunten osuus kangasmaista oli Keminkylässä noin 24 ja Sallan merkkipiirissä vain $10 \%$ (Mattila 2014). Pohjois-Sallassa jäkälälaitumilla porojen ulottuvilla $(<2 \mathrm{~m})$ yli 80-vuotiaissa varttuneissa ja vanhoissa metsissä luppoa on ollut myös erittäin vähän (Kumpula ym. 2009).

Perustietoja Sallan kunnasta ja alueen paliskunnista kerättiin aikaisemmasta tutkimuksesta (Siitari ym. 2003) ja Paliskuntain Yhdistyksen Poromies -lehdissä julkaistuista paliskuntien toimintakertomuksista. Tiedot Pohjois-Sallan ja Sallan paliskuntien yli 80 eloporoa omistavien poronomistajien Porotalouden (POMU) tuloslaskelmista kerättiin poronhoitovuosilta 2005/06-2012/13 Lapin ELY -keskuksesta. Tiedot pororuokakuntien porojen ruokintaa tukevista maataloustuista vuosilta 2005-13 kerättiin Sallan kunnasta.

\section{Tulokset ja tulosten tarkastelu}

Poronhoitovuosina 2005/06-2012/13 oli Pohjois-Sallassa 22-25 poronomistajaa, joilla oli > 80 eloporoa ja olivat siten eloporotuen piirissä ja mukana tutkimuksessa. Sallassa tällaisia oli enimmillään 25-31. Molempien paliskuntien poronomistajista oli elotuen piirissä vuosittain vain 1/5. Poronomistajien keski-ikä oli 43-50 vuotta. Ruokakunnissa oli vuosittain keskimäärin kaksi poronomistajaa. Ruokakuntien keskimääräinen karjakoko oli Pohjois-Sallassa 140-160, Sallassa 120-150 eloporoa. Molemmissa ruokakuntien keskimääräiset poromäärät kasvoivat tutkimusvuosina 10-15 porolla, ja vuonna 2012/13 molempien paliskuntien ruokakunnissa oli keskimäärin 155 eloporoa. Ruokakunnan porot olivat paljolti päämiehen omistuksessa (keskimäärin 110-130 eloporoa). Pohjois-Sallassa puolison omistuksessa oli vuosittain keskimäärin 25-60, Sallassa vain 10-15 eloporoa. Lapsilla oli Pohjois-Sallan ruokakunnissa keskimäärin vain 20-25, Sallassa 30-45 eloporoa. Pohjois-Sallan ruokakunnissa ja myös puolisoilla oli siten enemmän poroja kuin Sallassa. Sallassa ruokakuntien lapsilla oli keskimäärin enemmän poroja kuin Pohjois-Sallassa.

Poronhoitovuosina 2005/06-2012/13 Pohjois-Sallan paliskunnan poronomistajille maksamat pororahat olivat vuosittain keskimäärin 4 300-9 400 euroa. Sallassa summa oli hieman pienempi, noin 3 300-7 800 euroa. Molemmissa paliskunnissa pororahojen määrä pieneni tutkimusvuosina. Pohjois-Sallassa lasku oli enimmillään yli 5000 ja Sallassa yli 4000 euroa.

Pohjois-Sallassa suoramyynnin tulot poronomistajille olivat vuosittain keskimäärin noin 5 300-7 000 ja Sallassa 3 100- 6100 euroa. Molemmissa suoramyyntitulot kasvoivat tutkimusvuosien aikana. Muusta myynnistä saadut tulot olivat Sallan paliskunnassa pieniä, vuosittain keskimäärin vain noin 500 euroa. Pohjois-Sallassa muu myynti oli suurempaa, ja poronhoitovuosina 2008/09-2010/11 tulot olivat poronomistajille keskimäärin $1800-3000$ euroa. Pohjois-Sallassa muita myyntituloja sai vuosittain vain 2-4 poronomistajaa, Sallassa 3-8 poronomistajaa.

Pohjois-Sallassa poronomistajien myyntitulot olivat yhteensä 7 900- 12000 euroa, ja ne olivat poronhoitovuonna 2006/07 lähes 3000 euroa suuremmat kuin Sallassa. Molemmissa paliskunnissa teurasporoja oli runsaasti, Pohjois-Sallassa lähes 3340 enemmän kuin poronhoitovuonna 2012/13. Sallan paliskunnassa poronomistajien myyntitulot olivat vuosittain keskimäärin noin 8000-10000 euroa ja tutkimuksen loppuvuosina hieman suuremmat kuin Pohjois-Sallassa. Sallassa myyntitulot pienenivät vähän, PohjoisSallassa suuresti petovahinkojen vuoksi tutkimuksen lopulla.

Sallan paliskunnissa lähes kaikki tutkimuksen poronomistajat saivat poronhoitovuosina 2005/062012/13 hoitotyökorvauksia. Sallassa ne olivat vuosittain keskimäärin noin 2500 ja Pohjois-Sallassa 4500 euroa. Kahtena viimeisenä vuotena hoitotyökorvaukset kasvoivat Pohjois-Sallassa noin 7000 euroa. Lähes kaikki poronomistajat saivat paliskunnan maksamia korvauksia. Ne vaihtelivat vuosittain suuresti PohjoiSallassa, välillä 700-2 800 euroa. Sallassa nämä korvaukset olivat keskimäärin 800-1600 euroa/ poronomistaja. 
Lähes kaikki tutkimuksen poronomistajat saivat petokorvauksia Pohjois-Sallassa. Ennen poronhoitovuotta 2010/11 ne olivat vuosittain vielä melko alhaiset, keskimäärin vain 1 100-3 200 euroa/poronomistaja. Kolmena viimeisenä vuotena korvaukset nousivat nopeasti keskimäärin jo 10000 euroon/ poronomistaja. Muutaman poromiehen saamat petokorvaukset olivat vuosittain jo yli 30000 euroa. PohjoisSallan paliskunta on saanut viime vuosina myös vasahävikkikorvausta. Sallan paliskunnassa yleensä vain alle puolet poronomistajista sai petokorvauksia, ja ne vaihtelivat vuosittain keskimäärin välillä 800-2 700 euroa/poronomistaja. Sallan paliskunnassa petovahingot lisääntyivät vain vähän kolmena viimeisenä vuotena.

Pohjois-Sallassa autojen alle jäi vain 2-5 poronomistajan muutama poro, ja vuosittain keskimääräiset korvaukset/poronomistaja vaihtelivat välillä 200-1 300 euroa. Sallassa korvauksia sai vuosittain 6-18 poronomistajaa ja korvaukset vaihtelivat vuosittain välillä noin 770-2 300 euroa/poronomistaja. Tutkimuksen kolmena viimeisenä vuotena korvaukset auton alle jääneistä poroista kasvoivat suuresti Sallassa. Junan alle jäi neljänä vuotena vain 1-2 poronomistajan muutama poro ja keskimääräiset korvaukset olivat silloin 1002200 euroa/poronomistaja. Molemmissa paliskunnissa muutama poronomistaja sai vuosittain hieman myös muita korvauksia. Pohjois-Sallassa nämä korvaukset vaihtelivat suuresti vuosittain välillä 130-2 000 euroa, Sallassa välillä 360-1 300 euroa/poronomistaja.

Eloporotukea sai Pohjois-Sallassa vuosittain 21-24 poronomistajaa keskimäärin 3 150-4 400 euroa/ poronomistaja. Sallan paliskunnassa 21-27 poronomistajaa sai vuosittain eloporotukea keskimäärin noin 3004000 euroa/poronomistaja. Molemmissa paliskunnissa eloporotuen määrä kasvoi tutkimuksen aikana 1000 1500 euroa/poronomistaja. Aloitus- ym. tukia ja avustuksia sai tutkimusvuosina Pohjois-Sallassa 2-8 ja Sallassa vain1-3 poronomistajaa. Pohjois-Sallassa ne olivat keskimäärin 1 500- 8900 ja Sallassa 800-1 130 euroa/poronomistaja. Tutkimusvuosina 2005-13 Sallassa maataloustukea sai vuosittain 2-22 poronomistajaa keskimäärin noin 6900 euroa/poronomistaja. Pohjois-Sallassa maataloustukea sai vuosittain vain 2 poronomistajaa, mutta keskimäärin noin 7370 euroa/poronomistaja.

Pohjois-Sallan paliskunnassa muita tuloja sai vuosittain 21-25 poronomistajaa keskimäärin 10000 28000 euroa/poronomistaja. Muut tulot kasvoivat yli kaksinkertaisiksi poronhoitovuosina 2010/11-2011/12, mutta ne vähenivät jonkin verran viimeisenä vuotena. Sallassa muut tulot kasvoivat hieman, mutta 25-31 poronomistajan saamat muut tulot olivat vuosittain keskimäärin vain 12 000-15000 euroa/poronomistaja. Sallan paliskunnassa poronomistajien saamat tulot nousivat vain vähän ja olivat tutkimusvuosina keskimäärin noin 22 000-24 000 euroa/poronomistaja. Pohjois-Sallassa poronomistajien saamat tulot olivat tutkimuksen alkuvuosina samaa luokkaa kuin Sallassa, keskimäärin noin 21 500-23 000 euroa/poronomistaja. Loppuvuosina tulot kasvoivat korvausten ja muiden tulojen kasvun myötä nopeasti keskimäärin noin 35000 euroon/poronomistaja.

Molemmissa Sallan paliskunnissa oli useimmilla poronomistajilla tutkimusvuosina moottorikelkkojen ja rekien hankinta- ja käyttökuluja keskimäärin noin 900-1 900 euroa/poronomistaja. Useimmilla poronomistajilla oli myös pakettiautojen käyttökuluja keskimäärin noin 1 300-2 000 Pohjois-Sallassa ja 2090 3250 euroa/poronomistaja. Mönkijän käyttökuluja oli Pohjois-Sallassa vuosittain 13-16 poronomistajalla keskimäärin noin 770-1 350 euroa ja Sallassa 9-13 poronomistajalla vain 400-870 euroa/poron-omistaja. Porotalouden käyttökuluja oli useimmilla poronomistajilla molemmissa paliskunnissa: Pohjois-Sallassa keskimäärin noin 1 240-2 470 euroa ja Sallassa 1 200-2 700 euroa/poronomistaja. Hankintojen menot yhteensä olivat tutkimusvuosina Pohjois-Sallassa keskimäärin noin 3 170-5 980 euroa ja Sallassa 4 0205830 euroa/poronomistaja.

Pohjois-Sallassa poroja ruokki alkuvuosina vain 4 poronomistajaa, lopulla jo 9-10 poronomistajaa. Sallan paliskunnassa ruokki porojaan tutkimusvuosina 22-28 poronomistajaa. Pohjois-Sallassa porojen ruokintakulut olivat tutkimusvuosina keskimäärin vain noin 375-930 euroa/poronomistaja, ja poroja ruokittiin lähinnä vain paliskunnan eteläosassa (Kuva 1). Sallassa tarharuokintakulut olivat alkuvuosina keskimäärin 2 680-4 000 euroa/poronomistaja, mutta loppuvuosina jo noin 6000 euroa/poronomistaja.

Valtion, pankkien ja muiden lainojen korkoja oli molemmissa paliskunnissa vähän vain muutamalla poronomistajalla. Vuosittain lähes kaikki poronomistajat maksoivat paliskunnille porojen hoitomaksuja, Pohjois-Sallassa keskimäärin noin 5 280-7 450 euroa ja Sallassa 4 100-4800 euroa/poronomistaja. Molemmat paliskunnat perivät vuosittain osalta poronomistajista myös hieman muita maksuja. Molemmissa paliskunnissa monet poronomistajat maksoivat vuosittain MYEL -maksuja keskimäärin noin 1 100-1 800 euroa/poronomistaja. Muita pieniä vakuutusmaksuja ja kuluja maksoivat vain muutamat poronomistajat molemmissa paliskunnissa. Poronomistajien kulut ennen poistoja olivat tutkimusvuosina samaa luokkaa, Pohjois-Sallassa keskimäärin noin 11 550-15 300 euroa ja Sallassa 12 250-16 740 euroa/poronomistaja. 


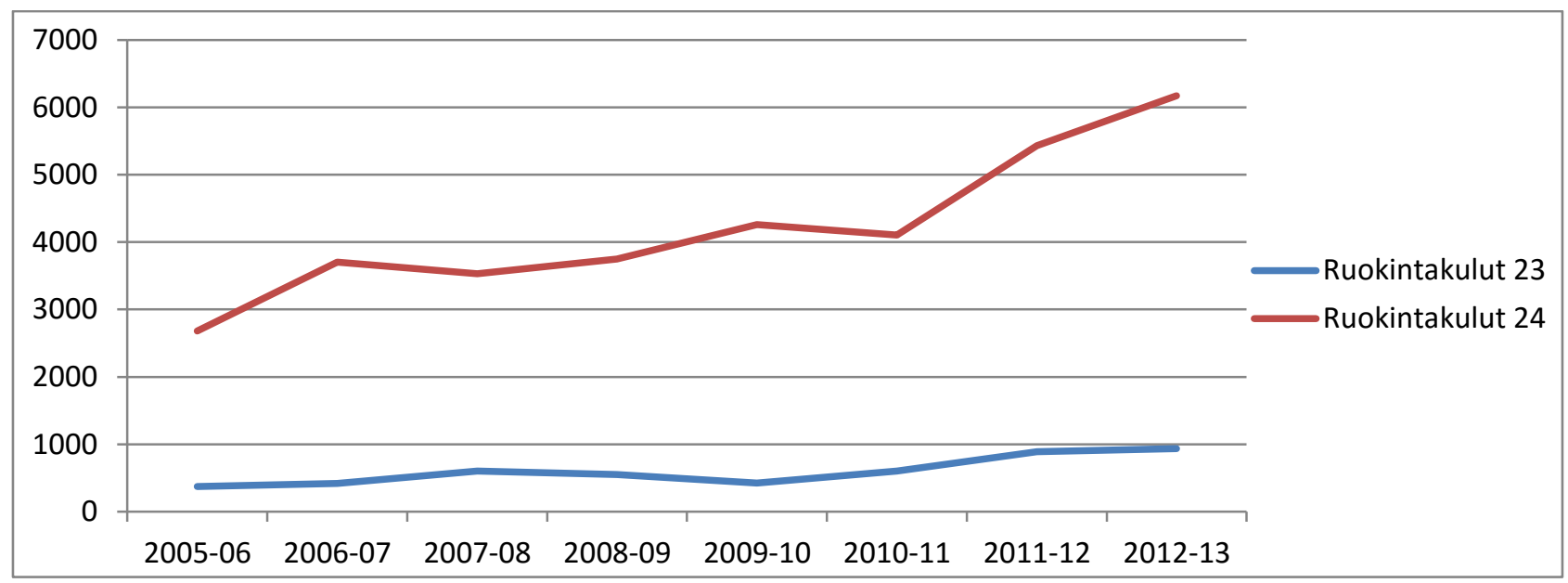

Kuva 1. Poronomistajien porojen keskimääräiset ruokintakulut (euroa/poronomistaja) Pohjois-Sallan (nro 23) ja Sallan (nro 24) paliskunnissa poronhoitovuosina 2005/06-2012/13.

Molemmissa Sallan paliskunnissa oli osalla poronomistajista poistoja kalustoluettelosta keskimäärin 2 000-4 000 euroa/poronomistaja. Pohjois-Sallassa kulut olivat tutkimuksen alussa keskimäärin noin 13 00014000 euroa ja viimeisinä vuosina jo noin 18000 euroa/poronomistaja. Sallassa kulut kasvoivat melko tasaisesti tutkimuksen aikana keskimäärin noin 13000 eurosta 17000 euroon/poronomistaja.

Porotalouden tulos ennen veroja ja omaa käyttöä oli tutkimusvuosina Pohjois-Sallassa keskimäärin noin 4 900-14 560 euroa ja Sallassa 810-3 800 euroa/poronomistaja. Veroja maksoi molemmissa paliskunnissa vuosittain vain muutama poronomistaja, Pohjois-Salla keskimäärin noin 260-1 200 euroa ja Sallassa 100-500 euroa/poronomistaja. Molemmissa paliskunnissa lähes kaikilla poronomistajilla oli omaa käyttöä: PohjoisSallassa keskimäärin noin 1 030-1 640 euroa ja Sallassa 950-1 670 euroa/poronomistaja.

Poroelinkeinon "pelkistetty" tulos vaihteli Pohjois-Sallassa tutkimusvuosina ilman peto- ja liikennevahinkokorvauksia sekä maataloustukia suuresti välillä keskimäärin 2000-7 700 euroa/poronomistaja (Kuva 2). Sallassa elinkeinon tulos oli tutkimusvuosina negatiivinen, keskimäärin noin 2000-6 000 euroa/poronomistaja.

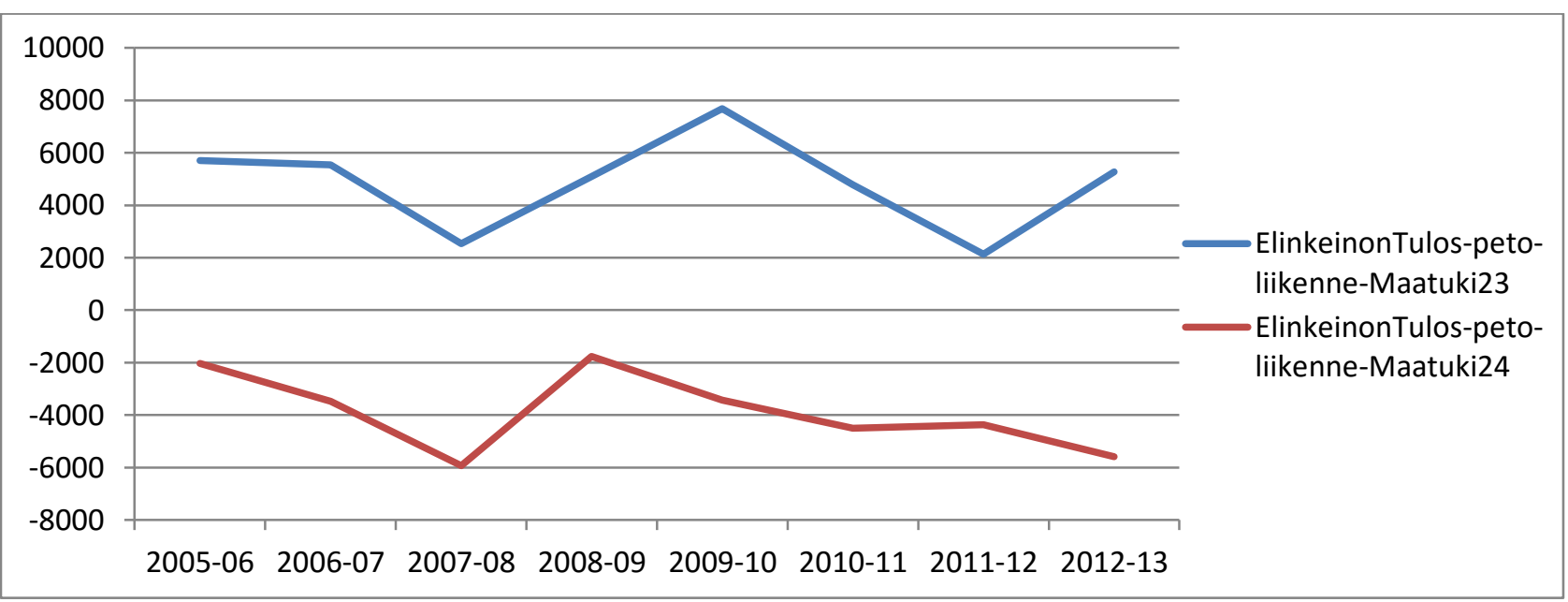

Kuva 2. Poroelinkeinon tulos (euroa/poronomistaja) Pohjois-Sallan (nro 23) ja Sallan (nro 24) paliskunnissa poronhoitovuosina 2005/06-2012/13, kun mukaan ei ole laskettu peto- ja liikennevahinkokorvauksia eikä maataloustukia.

Poroelinkeinon kokonaistulos Sallan paliskunnissa tutkimusvuosina ilman maataloustukea on esitetty kuvassa 3. Pohjois-Sallassa kokonaistulos kasvoi nopeasti ja suuresti tutkimuksen aikana ja oli lopussa keskimäärin yli 15000 euroa/poronomistaja. Sallassa kokonaistulos oli keskimäärin vain 2 000-4 000 euroa/ poronomistaja. 


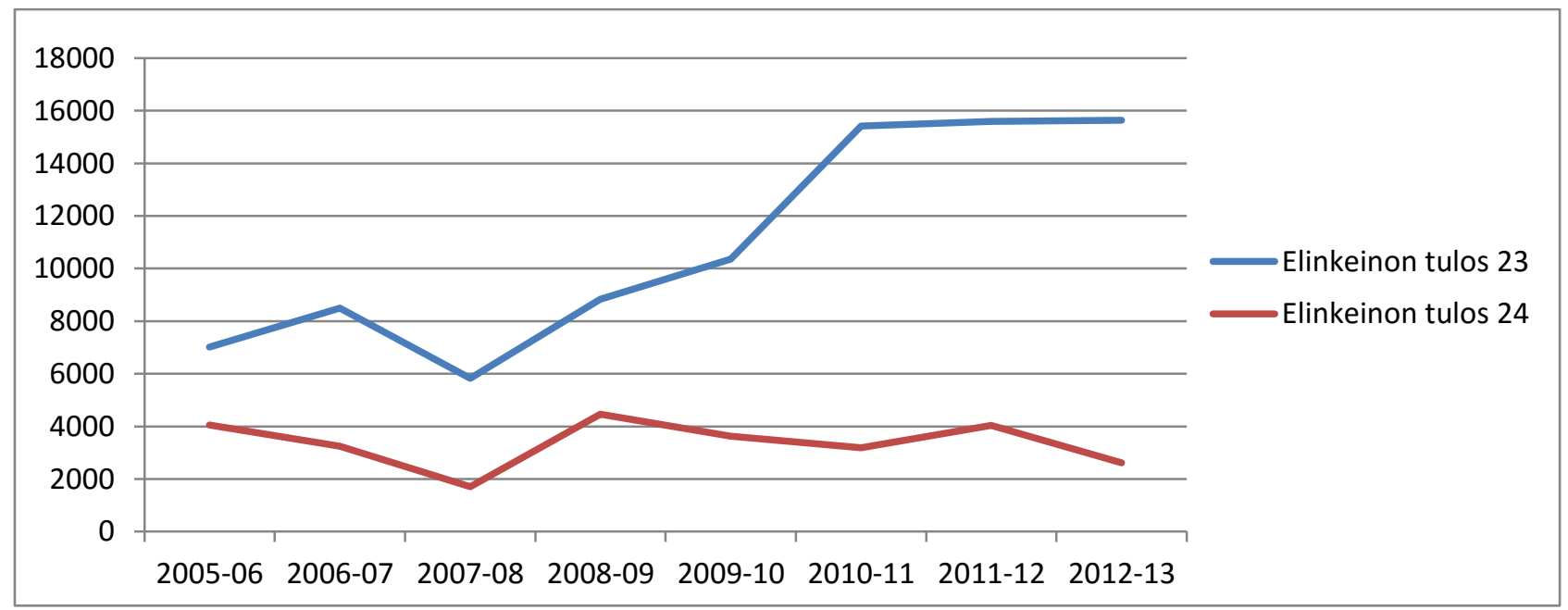

Kuva 3. Poroelinkeinon kokonaistulos (euroa/poronomistaja) Pohjois-Sallan (nro 23) ja Sallan (nro 24) paliskunnissa poronhoitovuosina 2005/06-2012/13. Mukaan on laskettu korvaukset petojen tappamista ja auton alle jääneistä poroista mutta ei maataloustukia.

Poroelinkeinon lopullinen kokonaistulos huomioiden myös maataloustuki oli Sallan paliskunnassa tutkimuksen alkuvuosina keskimäärin noin 6670-10000 euroa/poronomistaja, mutta laski kahtena viimeisenä vuotena noin 7230 euroon/poronomistaja (Kuva 4). Pohjois-Sallassa kokonaistulos oli ensimmäisinä vuosina noin 6680-9380 euroa/poronomistaja nousten nopeasti noin 19400 euroon/ poronomistaja. Viimeisenä tutkimusvuotena kokonaistulos tipahti noin 16240 euroon/poronomistaja.

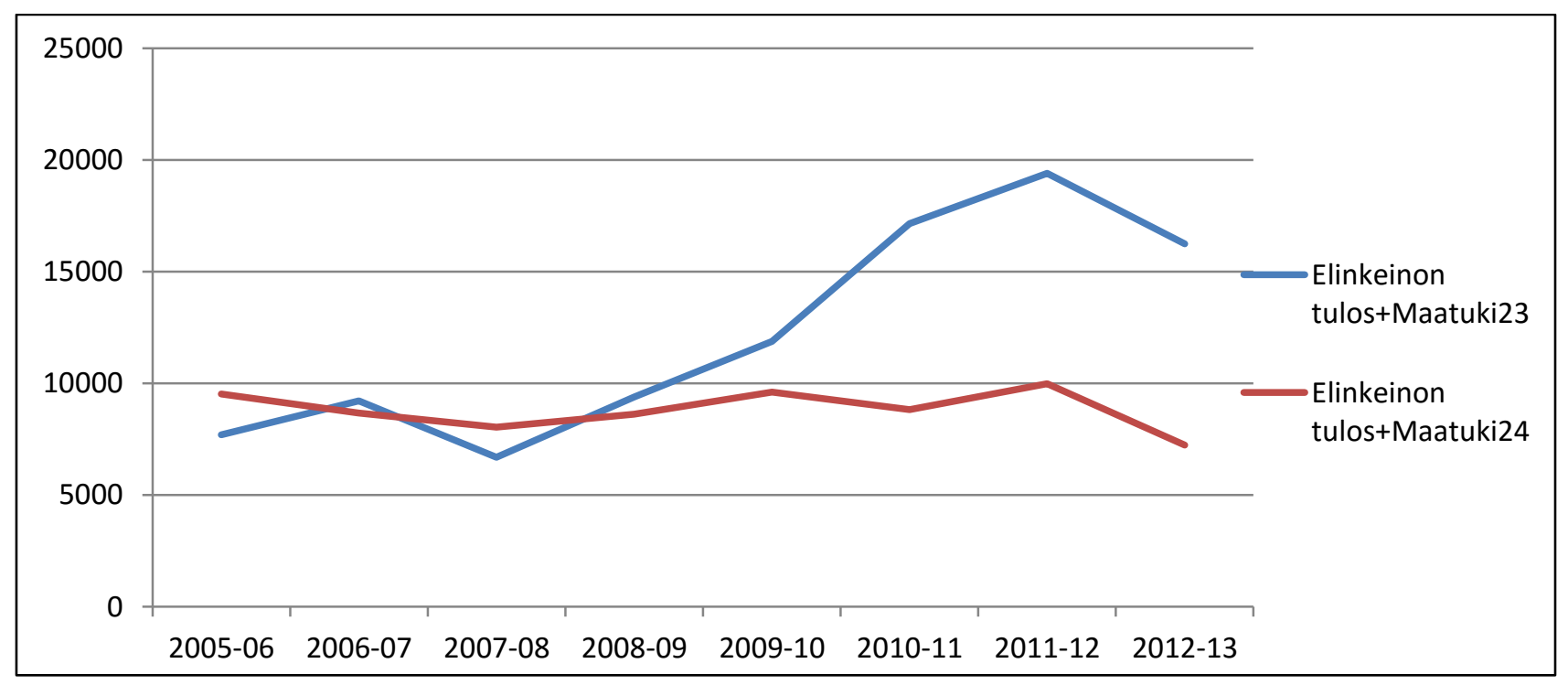

Kuva 4. Poroelinkeinon kokonaistulos (euroa/poronomistaja) Pohjois-Sallan (nro 23) ja Sallan (nro 24) paliskunnissa poronhoitovuosina 2005/06-2012/13. Mukaan on laskettu korvaukset petojen tappamista ja auton alle jääneistä poroista sekä saadut maataloustuet.

Sallan paliskunnassa porojen ruokintakulut, lähinnä tarharuokinnan rehukulut, olivat tutkimuksen lopussa vuosittain keskimäärin 6000 euroa/poronomistaja, eli noin 40 euroa/poro ja Pohjois-Sallassa vain 6 euroa/poro. Kaamasen koetarhalla ruokinnan kokonaiskulut (rehut, työ, koneet ja aidat) olivat kolmen kuukauden aikana normaalissa tarharuokinnassa 85 euroa/poro, ja hieman korkeammat kuin paimennustyyppisessä maastoruokinnassa (81 euroa/poro). Vapaassa tarharuokinnassa ruokintakulut olivat noin 116 euroa/poro, mutta vapaana luonnonlaitumilla laiduntavien, ilman ruokintaa olevien porojen hoito- ja paimennuskulut olivat vain 25 euroa/poro (Maijala \& Nieminen 2004). 


\section{Johtopäätökset}

Sallassa poronomistajien myyntitulot olivat vuosittain keskimäärin noin 8 000-12 000 euroa, ja tutkimuksen lopulla ne olivat hieman suuremmat Sallan paliskunnassa kuin suurista petovahingoista kärsivässä PohjoisSallassa. Kolmen viimeisen poronhoitovuoden aikana poronomistajien keskimääräiset myyntitulot vähenivät Pohjois-Sallassa petovahinkojen vuoksi noin 2000 euroa.

Lähes kaikki poronomistajat saivat petokorvauksia Pohjois-Sallassa, ja tutkimuksen kolmena viimeisenä vuotena ne nousivat nopeasti keskimäärin jo 10000 euroon/poronomistaja. Poronomistajien keskimäärinen petovahinkokorvaus kasvoi lähes 8000 eurolla eli nelinkertaisesti myyntitulojen laskuun verrattuna. PohjoisSallan paliskunta sai viime vuosina myös vasahävikkikorvausta. Sallassa 6-18 poronomistajaa sai puolestaan vuosittain korvauksia auton alle jääneistä poroista vuosittain keskimäärin 770-2 300 euroa/poronomistaja. Ruokinta ja kesyyntyminen tuovat poroja nykyään yhä useammin taajamiin, teille, pihoille ja pelloille lisäten entisestään myös liikennevahinkoja (Nieminen 2013). Tutkimuksen kolmena viimeisenä vuotena nämä korvaukset kasvoivat suuresti. Pohjois-Sallassa poronomistajien tulot nousivat nopeasti petovahinkojen korvausten myötä keskimäärin 35000 euroon/poronomistaja.

Sallan paliskunnassa ruokintakulut olivat alkuvuosina keskimäärin 2 680-4 000 ja loppuvuosina jo noin 6000 euroa/poronomistaja. Maataloustuen määrä oli vuosittain kuitenkin ruokintakuluja suurempi, keskimäärin noin 6900 euroa/poronomistaja. Pohjois-Sallassa poroelinkeinon "pelkistetty" tulos ilman petoja liikennevahinkokorvauksia sekä maataloustukia vaihteli tutkimusvuosina suuresti ja oli keskimäärin noin 2 000-7 700 euroa/poronomistaja. Sallassa tulos oli ruokintakuluista johtuen vuosittain negatiivinen, keskimäärin 2 000-6 000 euroa/poronomistaja.

Pohjois-Sallassa poroelinkeinon kokonaistulos oli ensimmäisinä vuosina samaa luokkaa kuin Sallassa nousten nopeasti keskimäärin noin 19400 euroon, mutta se tipahti vähäisten teurasmäärien vuoksi lopussa 16240 euroon/poronomistaja. Sallassa kokonaistulos oli vahinkokorvauksineen ja maataloustukineen alkuvuosina keskimäärin 6 670-10 000 euroa/poronomistaja, mutta se laski kahtena viimeisenä vuotena noin 7230 euroon/poronomistaja. Veroja maksoi molemmissa paliskunnissa vuosittain vain muutama poronomistaja. Porotalous oli siten lähes kaksi kertaa kannattavampaa Pohjois-Sallassa kuin porojen ruokintaa harjoittavassa Sallan paliskunnassa. Tutkimustulosten mukaan poroja pitäisi hoitaa paremman kannattavuuden, mutta myös hyvän imagon vuoksi enemmän luonnonlaitumilla. Porolaidunten riittävyyteen, kuntoon ja poromääriin pitäisi kiinnittää huomiota jo kasvavien liikenne- ja petovahinkojen vuoksi koko poronhoitoalueella (Nieminen 2015b).

\section{Kirjallisuus}

Kumpula, J., Colpaert, A. \& Nieminen, M. 1999. Suomen poronhoitoalueen kesälaidunvarat. - Kala- ja Riistaraportteja nro 152, 40 sivua.

Kumpula, J., Tanskanen, A., Colpaert, A., Anttonen, M., Törmänen, H., Siitari, J. \& Siitari, S. 2009. Poronhoitoalueen pohjoisosan talvilaitumet vuosina 2005-2008. Laidunten tilan muutokset 1990-luvun puolivälin jälkeen. - Riista- ja Kalatalous - Tutkimuksia 3/2009, 48 sivua.

Maijala, V. \& Nieminen, M. 2004. Poron ympärivuotinen ruokinta ja sen kannattavuus. - Kala- ja Riistaraportteja nro 304, 46 sivua, 4 liitettä.

Mattila, E. 2012. Porojen laitumia koskevia arviointituloksia 1970-luvulta alkaen. Neljä laidunarviointia valtakunnan metsien inventoinnin yhteydessä vuosina 1976-2004. - Metlan työraportteja 238, 100 sivua.

Mattila, E. 2014. Porojen talvilaitumien määrä ja laatu poronhoitoalueen etelä- ja keskiosissa. - Metlan työraportteja 304, 64 sivua.

Mattila, E. \& Mikkola, K. 2009. Poronhoitoalueen etelä- ja keskiosien talvilaitumet. Tila paliskunnissa 2000-luvun alkuvuosina ja eräiden ravintokasvien esiintymisrunsauden muutokset merkkipiireissä1970-luvulta lähtien. - Metlan työraportteja 115, 57 sivua.

Nieminen, M. 2015a. Poronhoitotapojen kannattavuus kahdessa Sallan kunnan paliskunnassa. Loppuraportissa: Porotalouden kilpailukyky muuttuvissa olosuhteissa, Kaija Saarni (toim.), sivut 4-11. Luonnonvarakeskus, Luke 31.8.2015, 23 sivua.

Nieminen, M. 2015b. Porotaloudessa pitäisi leikata. Lapin Kansa 31.5.2015.

Nieminen, M. 2013. Response distances of wild forest reindeer (Rangifer tarandus fennicus Lönnb.) and semi-domestic reindeer (R. t. tarandus L.). - Rangifer 33(1): 1-15.

Nieminen, M. 2010. Poron talvilaidunten käyttö ja kunto Pohjois-Suomen luonnonsuojelu- ja erämaa-alueilla. - Riistaja Kalatalous - Tutkimuksia 3/2010, 36 sivua.

Siitari, S., Kemppainen, J., Kettunen, J. \& Nieminen, M. 2003. Porotalous Sallan kunnassa. - Kala- ja Riistaraportteja nro 274,45 sivua. 